\title{
Pollution Prevention Opportunity Assessment United States Naval Base Norfolk Naval Air Station
}

Dan Bowman and Jan DeWaters

This report summarizes work conducted at the U.S. Navy's Naval Base Norfolk, Naval Air Station (NAS) located at Sewells Point in Norfolk, VA under the U.S. Environmental Protection Agency's (EPA's) Waste Reduction Evaluations at Federal Sites (WREAFS) Program, with support provided under the Strategic Environmental Research and Development (SERDP) Program. SERDP is a cooperative effort between DOD, DOE and EPA to develop environmental solutions that enhance mission readiness in Defense operations.

Under the Chesapeake Bay Agreement, Naval Base Norfolk is a member of the Tidewater Interagency Pollution Prevention Program. At NAS Norfolk, the Navy and EPA have evaluated techniques and technologies to reduce waste generation from cooling tower operations, cooperating on the Pollution Prevention Opportunity Assessment which identified areas for waste reduction during operation and maintenance of the NAS cooling towers. The study followed procedures outlined in EPA's Facility Pollution Prevention Guide. Opportunities were identified for reducing the generation of waste from cooling tower water treatment operations. The options for changes in operational and treatment processes and procedures were evaluated for their potential to achieve pollution prevention objectives, as well as for technical and economic feasibility.

This Project Summary was developed by EPA's National Risk Management
Research Laboratory, Cincinnati, $\mathrm{OH}$, to announce key findings of the research project that is fully documented in a separate report of the same title (see Project Report ordering information at back).

\section{Introduction}

The purposes of the WREAFS Program are to identify new technologies and techniques for reducing wastes from process operations and other activities at Federal sites, and to enhance the implementation of pollution prevention/waste minimization through technology transfer. New techniques and technologies for reducing waste generation are identified through waste minimization opportunity assessments and may be further evaluated through joint research, development, and demonstration projects.

A cooling tower is an enclosed device designed for the evaporative cooling of water by direct contact with air. Cooling towers are used in conjunction with air conditioning and industrial process equipment, acting as the heat sink for these systems by providing a continuous source of cool water for process operations. Opensystem recirculating cooling towers are typically chosen for operation with air conditioning and refrigeration equipment because they are relatively inexpensive and minimize heat rejection costs while conserving water.

All of the cooling towers at the Norfolk Naval Air Station identified in this PPOA are of the recirculating, open-system type. The Navy and EPA are currently evaluat- 
ing techniques and technologies to reduce wastes generated from cooling tower operations within the Norfolk NAS. Approximately 28 open-system recirculating cooling towers are currently operated at 18 buildings within the NAS. These units range in size from 5 to 300 tons, and are all associated with comfort cooling systems that operate on a seasonal basis (approximately $6 \mathrm{mo} / \mathrm{yr}$ ).

\section{General Process Description}

Approximately 598 buildings or structures are located at the Norfolk NAS. Of these, 18 buildings are equipped with air conditioning systems that operate in conjunction with evaporative recirculating cooling towers for a continuous supply of process water. The air conditioning systems provide comfort cooling during warm spring and summer months, largely between April and October. The NAS cooling towers do not operate during the cool season. Table 1 is a master equipment list of the 28 cooling towers providing process water for the air conditioners which service these 18 buildings. As described in Table 1, these cooling towers are located on building roofs, adjacent to an exterior wall, or in a courtyard outside of the building and range in capacity from 5 to 300 tons. One cooling tower ton is equivalent to the removal of 15,000 BTU/ hr.

Table 1 indicates that only 10 of the 28 towers are currently receiving chemical treatment for control of scale, corrosion, and biological fouling. The remaining 18 towers are primarily small units and do not receive chemical treatment during the operating season.

The last column in Table 1 lists the system water volume in gallons for the 10 towers receiving treatment. The volumes are used to derive some of the alternative treatment costs. These system volumes, estimated by Base personnel, depend to a large extent on unit size, but are also

Table 1. Master Equipment List - Cooling Towers at Norfolk Naval Air Station

Equipment \#

Building

Location

Size (Tons)

Volume (Gallons)

Cooling Towers Receiving Chemical Treatment*

$\begin{array}{lllrr}081275 & \text { SP367 } & \text { East outside } & 75 & 127 \\ - & \text { SP254** } & \text { Roof } & 200 & 600 \\ - & \text { SP256** } & \text { Roof } & 200 & 1,000 \\ 028197 & \text { V53 } & \text { Roof } & 150 & 1,200 \\ 028198 & \text { V53 } & \text { Roof } & 175 & 1,400 \\ 021087 & \text { SP29**} & \text { West courtyard } & 300 & 3,500 \\ 024341 & \text { U16** } & \text { East side } & 300 & 2,500 \\ 081218 & \text { SP45 } & \text { South side } & 125 & 1,250 \\ 093171 & \text { SP91 } & \text { Behind building } & 100 & 1,000 \\ 093172 & \text { SP91 } & \text { Behind building } & 40 & 400\end{array}$

Cooling Towers Not Receiving Treatment****

\begin{tabular}{|c|c|c|c|c|}
\hline 022189 & $L P 13$ & Roof east side & 25 & $N / A$ \\
\hline 080394 & $\angle P 13$ & Roof west side & 25 & $N / A$ \\
\hline 086933 & $\angle P 13$ & Roof west side & 25 & $N / A$ \\
\hline 080385 & $L P 2$ & Roof west side & 25 & $N / A$ \\
\hline 080386 & $\angle P 2$ & Roof east side & 25 & $N / A$ \\
\hline 080387 & $\angle P 3$ & Roof west side & 25 & $N / A$ \\
\hline 080388 & $\angle P 3$ & Roof east side & 25 & $N / A$ \\
\hline 022188 & $L P 4$ & Roof east side & 25 & $N / A$ \\
\hline 080389 & LPA & Roof west side & 25 & $N / A$ \\
\hline 052754 & $\$ 33$ & Roof & 20 & $N / A$ \\
\hline 086998 & S33 & West side & 5 & $N / A$ \\
\hline 093369 & SP238 & South end & 20 & $N / A$ \\
\hline 097454 & SP64 & Outside building & 20 & $N / A$ \\
\hline 021751 & T26 & Roof east side & 20 & $N / A$ \\
\hline 085676 & T26 & Roof west side & 60 & $N / A$ \\
\hline 085677 & T26 & Roof & 60 & $N / A$ \\
\hline 050597 & $\cup 48$ & West side & 7.5 & $N / A$ \\
\hline 083286 & V82 & Roof & 45 & $N / A$ \\
\hline
\end{tabular}

- Refers to status of treatment at the time of report preparation, August 1994.

"*Chemical treatment has been instituted at these new units since the site visit in June 1994.

**"The cooling towers currently not receiving treatment are designed for chemical treatment.

-These two new units have not yet been issued equipment identification numbers. influenced by the cooling tower locations and piping systems.

\section{Cooling Tower Discharge Practices}

All cooling towers at the NAS receive makeup water from the City of Norfolk public water supply. Each of the cooling towers is equipped with a discharge valve which directed the tower blowdown into floor drains located in the vicinity of the heat exchanger and condensed water pump.

\section{Cooling Tower Maintenance Activities}

Maintenance and operation of the cooling towers and air conditioning units are performed by the Public Works Command (PWC), under contract to the NAS. PWC personnel do not currently have a systematic method for managing the NAS cooling towers. Ten of the 28 NAS cooling towers are serviced under a chemical treatment contract to PWC by one of two water treatment specialists. Each of these 10 units is maintained by a treatment representative, whose primary responsibility includes cooling tower water testing and treatment.

The remaining towers, which are not serviced by a chemical contractor, are the responsibility of the PWC mechanics. These units receive no chemical treatment during the operating season aside from the occasional addition of biocide to control excessive fouling. General maintenance activities for the cooling towers not serviced by a water treatment specialist include an annual overhaul of each unit, which is performed during the winter months while the unit is not operating.

Following the annual overhaul, PWC maintenance personnel apply an algicide to each of the cooling tower units not serviced by a chemical contractor. A 1-gal container of algicide is fed by continuous drip to each unit to control biological growth in the system. Some of the towers may occasionally receive additional biocide during the operating season to control excessive biological fouling, although application rates and schedules vary.

\section{Chemical Addition Program}

At the Norfolk NAS, PWC personnel purchase the chemicals, and a water treatment contractor tests the tower water, adjusts control parameters such as bleed and makeup water flowrates, and administers chemicals as needed.

Of the 28 towers in operation, 10 are currently receiving chemical treatment, and are serviced under contract by one of two cooling tower water treatment specialists 


\section{DISCLAIMER}

This report was prepared as an account of work sponsored by an agency of the United States Government. Neither the United States Government nor any agency thereof, nor any of their employees, makes any warranty, express or implied, or assumes any legal liability or responsibility for the accuracy, completeness, or usefulness of any information, apparatus, product, or process disclosed, or represents that its use would not infringe privately owned rights. Reference herein to any specific commercial product, process, or service by trade name, trademark, manufacturer, or otherwise does not necessarily constitute or imply its endorsement, recommendation, or favoring by the United States Government or any agency thereof. The views and opinions of authors expressed herein do not necessarily state or reflect those of the United States Government or any agency thereof. 


\section{DISCLAIMER}

Portions of this document may be illegible in electronic image products. Images are produced from the best available original document. 
who also service other units on base. Four of these units are equipped with chemical pumps and metering systems but were not included in a chemical treatment contract at the time of the site visit in June 1994. Chemical treatment programs have recently been implemented at these four units. In the future, all towers at the NAS would be included in a chemical addition program.

\section{General Procedure for Chemical Procurement}

The procedure for procurement and administration of water treatment chemicals involves a cooperative effort between appropriate PWC personnel and the water treatment or chemical contractor responsible for the unit. Each of the cooling towers under contract to a water treatment specialist is inspected sporadically to ensure that the tower is operating properly and is receiving adequate chemical treatment. Operating malfunctions are adjusted and corrected by the contractor. If the contractor determines that additional chemicals must be purchased, PWC is notified. PWC personnel order the appropriate materials for delivery to the specific building at the specific zone on base. Once the chemicals arrive on site, the contractor returns to administer treatment.

PWC personnel who were interviewed during the site visit stated that under no circumstances do PWC maintenance personnel administer chemicals to the NAS cooling towers, regardless of whether or not the towers are maintained under contract by a water treatment specialist. However, at the time of the site visit, two towers were observed that were not currently under contract by a water treatment specialist, but that were connected to a chemical holding tank and an engaged metering pump. Thus, the actual chemical administration procedures as practiced remain somewhat uncertain.

A chemical exchange program exists within each zone on base. Most chemicals are stored in the mechanical room of the building in which they are used. As more chemicals are needed by a particular building, PWC will first check to see that excess chemicals do not exist in storage at another building before ordering a new supply. This procedure avoids stockpiling of surplus chemicals.

\section{Chemical Descriptions and Usage Data}

The chemicals used for cooling tower water treatment at the Naval Air Station are presented in-Table 2 along with their primary ingredients, type of control, appli- cation rate, and frequency of use. Typical application rates for each chemical, shown in Table 2, have been combined with cost information to estimate annual usage rates and associated costs. Usage rates are based on a 6-mo operating season, and assume that all towers operate with 4 cycles of concentration at $100 \%$ capacity for $12 \mathrm{hr} /$ day. As described above, the chemicals applied to each of the NAS cooling towers, which total approximately 814 gal, are ultimately discharged to the environment through tower bleed. The total annual chemical costs for the NAS cooling towers currently receiving chemical treatment are estimated at $\$ 13,900$. For water usage, Table 3 provides bleed rates and make up requirements with monthly costs.

\section{Description of Available Options}

\section{Non-treatment}

Although non-treatment alternatives may eliminate the application and subsequent discharge of cooling tower water treatment chemicals, these may entail excess water usage rates to control the accumulation of suspended solids in the system. In addition, improper treatment and management of cooling tower water may result in excessive buildup of scale deposits and biological fouling, ultimately resulting in system failure.

\section{Option 1. No Treatment}

Eighteen of the NAS cooling towers currently have no formal chemical treatment program. One option for pollution prevention is to extend this practice to all 28 NAS cooling towers. Under this scenario, the towers would receive annual maintenance. During the off-season, the units would be externally cleaned with wire or nylon brushes, the heat exchanger end plates would be removed, and the tubes roddened with a round wire brush to remove scale deposits as needed. Approximately one gal of algicide would be added to each unit by means of a drip feed.

Refraining from chemical treatment would result in the annual consumption of approximately $28 \mathrm{gal}$ of algicide at a cost of approximately $\$ 15$ each, for a total of $\$ 420.00 / y r$. This represents a savings of approximately $\$ 13,300$ annually in chemical costs, and a substantial reduction in the discharge of cooling tower water treatment chemicals to the environment. However, failure to properly maintain the towers during the operating season results in the buildup of scale deposits and significant algal growth, often leading to operational down-time for necessary repair work and mid-season cleaning. This is costly in terms of employee man-hours. In addition, the operational lifetime of a unit, typically in the range of 15 to $20 \mathrm{yr}$, is significantly reduced by improper maintenance and also by failure to provide adequate corrosion protection. Systems clogged by excessive scale deposits often require acid dosing to clear blocked passageways; this is an aggressive treatment procedure and can be harmful to the materials of construction, especially where corrosion has already exposed oxidized portions of the metallic surface. Thus, while a no-treatment option appears to be cost effective in terms of operating expenses, ultimately, the expense of new equipment purchases due to system failure makes this option less attractive.

\section{Option 2. Continuous Bleed-off or Blowdown}

The purpose in using recirculating cooling systems is to conserve makeup water. Systems using higher cycles of concentration use less water. Achievable cycles of concentration depend on the concentration of ions such as calcium and silica in the makeup water, since these accumulate throughout evaporative losses which take place in the cooling tower. The risk of severe scale or corrosion problems increases dramatically with higher cycles of concentration. Solids and impurities will continue to accumulate until the system water is removed through bleed-off or blowdown. Dissolved oxygen increases in a recirculating system because the water is reaerated during each passage through the cooling tower. In normal practice, a portion of the recirculating water will be removed through system blowdown in order to maintain the concentration of dissolved solids and gases at a required level, thereby preventing scale deposits and corrosion.

Maximum concentration factors are recommended for open cooling water systems according to the hardness of the water and the type of treatment applied. Systems receiving makeup water of relatively low hardness or those which receive effective scale-inhibiting treatment may operate at high concentration factors, maximizing the portion of recirculating water and minimizing the makeup water requirements. Without treatment, concentration values of about 3 to 7 are enough to cause some salts to precipitate out as scale. Various water treatment approaches and devices have historically avoided scale formation by increasing the bleed and makeup water rates rather than control- 
Table 2. Treatment Chemicals Currently Used in Norfolk NAS Cooling Towers

\begin{tabular}{|c|c|c|c|c|}
\hline Trade Name & Principal Ingredients & Type of Control & Application Rate & Usage Rate \\
\hline \multicolumn{5}{|c|}{ Chemicals Used in Cooling Towers for Buildings SP367, SP254, and SP256 } \\
\hline Formula $1100^{*}$ & $\begin{array}{l}\text { Poly [oxyethylene-(dimethyliminio) ethylene- } \\
\text { (dimethyliminio) ethylene dichloride] }\end{array}$ & Biocide & $\begin{array}{l}2 q t / w k / 300 \text { ton } \\
1 / 2 \text { qt/wk/100 ton }\end{array}$ & $\begin{array}{l}1 / w k \\
1 / w k\end{array}$ \\
\hline Formula $1109^{*}$ & $\begin{array}{l}\text { Disodium ethylene bisdithiocarbamate } \\
\text { sodium dimethyldithiocarbamate } \\
\text { ethylene thiourea }\end{array}$ & Biocide & $\begin{array}{l}2 q t / w k / 300 \text { ton } \\
1 / 2 \text { qtwk/100 ton }\end{array}$ & $\begin{array}{l}1 / w k \\
1 / w k\end{array}$ \\
\hline Formula 2055 & $\begin{array}{l}\text { Sodium hydroxide } \\
\text { methylene phosphonic acid }\end{array}$ & $\begin{array}{l}\text { Scale/corrosion } \\
\text { inhibitor }\end{array}$ & 1 qt/100 ton/day & Continuous \\
\hline Formula 7200 & $\begin{array}{l}\text { Potassium hydroxide } \\
\text { 1-hydroxyethylidene-1, 1-disphosphonic acid }\end{array}$ & $\begin{array}{l}\text { Dispersant/ } \\
\text { antifoulant }\end{array}$ & $\begin{array}{l}\text { approximately } \\
30 \text { gal/yr }\end{array}$ & $\begin{array}{l}\text { At start-up and } \\
\text { shutdown }\end{array}$ \\
\hline
\end{tabular}

Chemicals Used in Cooling Towers for Buildings SP45, SP91, V53, SP29 and U16

\begin{tabular}{|c|c|c|c|c|}
\hline Dicaton & Sodium hydroxide & Non-Acid descaler & $\begin{array}{l}2.5 \mathrm{gal} / 1,000 \mathrm{gal} \text { system } \\
\text { water }\end{array}$ & $\begin{array}{l}\text { At start-up or } \\
\text { cleanup }\end{array}$ \\
\hline$G A X-16^{*}$ & Poly ethylene- ethylene dichloride & Biocide & $\begin{array}{l}1 / 4 \text { to } 1 / 2 \mathrm{pt} / 1,000 \mathrm{gal} \\
\text { makeup water** }\end{array}$ & 1/every other wk \\
\hline GAX-20* & 2,2-dibromo-3 nitrilopropionamide & Biocide & $\begin{array}{l}1 / 4 \text { to } 1 / 2 \mathrm{pt} 1,000 \mathrm{gal} \\
\text { makeup water }\end{array}$ & 1/every other wk \\
\hline GCO-10-LM & $\begin{array}{l}\text { Sodium molybdate } \\
\text { polyethylene- ethylene dichloride }\end{array}$ & $\begin{array}{l}\text { Scale/corrosion } \\
\text { inhibitor } \\
\text { w/ biocide }\end{array}$ & $\begin{array}{l}1 / 2 \text { to } 1 \mathrm{pt} / 1,000 \mathrm{gal} \\
\text { makeup water** }\end{array}$ & Continuous \\
\hline$G C 0-10$ & Poly ethylene-ethylene dichloride & $\begin{array}{l}\text { Scale/corrosion } \\
\text { inhibitor } \\
\text { w/biocide }\end{array}$ & $\begin{array}{l}1 / 2 \text { to } 1 \mathrm{pt} / 1,000 \mathrm{gal} \\
\text { makeup water** }\end{array}$ & Continuous \\
\hline
\end{tabular}

ling calcium carbonate or silicate formation by chemical or mechanical means.

Minimum dissolved solids and mineral concentrations could be maintained by operating the cooling tower with a continuous supply of fresh water and a maximum flow of tower bleed. A once-through system would avoid the buildup of solids, gases and impurities in the process water, thereby limiting the potential for scale deposits and corrosion, and would eliminate the need for administration and discharge of chemicals to the environment through cooling tower blowdown. However, the high operating costs of large amounts of makeup water make this a fairly unattractive option. Makeup water requirements and associated costs are reduced drastically by operating at higher cycles of concentration.

Although a continuous bleed will avoid the buildup of dissolved solids and gases, the potential still exists for algal and bacterial growth. Thus, the system may still malfunction during the operating season if the biofouling is allowed to progress. Each cooling tower unit should still receive an annual overhaul and application of a 1-gal biocide drip, which will increase annual operating costs accordingly.

\section{Additional Options and Recommendations}

In addition to the two pollution prevention options identified above, the PPOA team noted 6 alternative treatment options available. Table 4 provides an overview of all the options. A detailed discussion of the treatment options is provided in the full report. Three technologies described, including the DIAS-AID Tower Treatment XP-300, the KDF process, and the magnetic treatment application combined with integrated technologies, are attractive economically as well as for pollution prevention. Recommendations for further research 
Table 3. Bleed and Makeup Water Requirements and Monthly Costs at Different Cycles of Concentration*

\begin{tabular}{lrrrrrr} 
Cycles of Concentration & 2 & 3 & 4 & 5 & 10 & 8 \\
\hline Evaporation $(g p m)$ & 3 & 3 & 3 & 3 & 3 & 3 \\
Total bleed rate $(\mathrm{gpm})$ & 3 & 1.5 & 1 & 0.75 & 0.4 & 33 \\
Makeup water $(\mathrm{gpm})$ & 6 & 4.5 & 4 & 3.75 & 3.4 & $\$ .33$ \\
Water cost $(\$ / \mathrm{mo})^{* *}$ & $\$ 443.09$ & $\$ 335.07$ & $\$ 297.84$ & $\$ 279.22$ & $\$ 253.16$ & $\$ 247.95$ \\
\hline
\end{tabular}

"Assumes a 100-ton open-system recirculating cooling tower operating at full capacity for $12 \mathrm{hr} / \mathrm{day}$, with a $10^{\circ} \mathrm{F}$ temperature drop across the tower. Pump circulation rate is $300 \mathrm{gal} / \mathrm{min}$.

* Costs are based on a combined water and sewer cost of $\$ 3.40 / 1000$ gal. Norfolk City water prices are currently $\$ 1.34 / 1000$ gal, and sewer prices are $\$ 2.06 / 1000 \mathrm{gal}$. Since cooling towers at the Norfolk NAS are generally not provided separate metering systems for drainage, combined rates are charged for makeup water. It is obvious from the above table that as the operating cycles of concentration increase, the volume of bleed discharged to the drain is substantially reduced. Separate metering systems would allow calculation of a credit for makeup water which is not discharged to the drain (e.g., evaporative losses), and would result in substantial savings.

Table 4. Summary of Treatment Options: Advantages and Disadvantages

\section{Treatment Option}

1. No Treatment

2. Continuous bleed

3. Conventional chemical addition

4. DIAS-aid tower treatment XP-300

5. pH adjustment

6. Base exchange and ion exchange processes

7. KDF process

8. Magnetic applications
Advantages

- Minimal chemical costs

-Minimal discharge of chemicals to environment

- Minimal chemical costs

-Minimal discharge of chemicals to environment

-Fairly reliable method

- Several chemical options available for customized treatment

-Recently developed product which has demonstrated effective treatment

- Operates with little or no system bleed

- Cost effective, in terms of chemical and water use

- Minimal chemical costs; sulfuric acid an economical choice - Minimal discharge of chemical to environment

- Minimal chemical costs

- Minimal discharge of chemical to environment

-Produces soft, non-scaling water

- Minimal chemical costs

- Minimal discharge of chemical to environment

- Waste product consists of recyclable metallic alloy

-System is self-regulating by responding to changes in $\mathrm{pH}$

-Minimal chemical costs

- Minimal discharge of chemical to environment

- Lifetime warranty

- Minimizes maintenance demands

- Effective against scale and corrosion
Disadvantages

- High maintenance demands

- Poor system operation

-Reduced operating lifetime of equipment

-Excessive water consumption and associated costs

- Treatment can be costly in terms of chemicals purchased, required testing and maintenance

-Chemicals may be limited in discharges

- Limited operating experience on which to base a level of confidence

-Additional intermittent treatment may be needed for control of biological growth

- Difficult to maintain adequate control

- Undesirable dissolved solids may still accumulate in system

- Softened water may be corrosive

- Generally quite expensive

-Provide scale control only

- Limited operating experience on which to base a level of confidence

-Additional filter unit necessary for solids removal

- May cost slightly more than conventional chemical treatment

- Operating experience shows inadequate control over microbial growth; dosing with biocide or acid may be necessary to maintain a clean system

- Limited operating experience on which to base a level of confidence

-Additional sidestream treatment usually necessary

for solids removal

-Additional control may be required for microbial growth 
Table 4. (continued)

Treatment Option

9. Ozonation, U.V. light treatment

10. Sidestream treatment

\section{Advantages}

- Minimal chemical costs

- Minimal discharge of chemical to environment -Effective Sterilization Techniques

-Effective treatment for solids removal and control of fouling

- Minimal chemical costs

- Minimal discharge of chemical to environment

-Several options are available

\section{Disadvantages}

- Generally quite expensive

-U.V. limited to small size; ozone limited to larger size units

- Not effective against scale or corrosion

- Generally used in conjunction with another treatment method to reduce solids and the potential for microbial growth; not an effective stand-alone treatment methodology include site visits to facilities which employ each of these three types of treatment technologies, in order to gather operating data and to observe the systems in operation. Additional information gained through site visits would be used to select an appropriate technology option to be used in a demonstration project designed to evaluate the potential for effectively treating the NAS cooling tower water.
The full report was submitted in fulfillment of Contract No. 68-D2-0181, Work Assignment No. 1-011by TRC Environmental Corp. under the sponsorship of the U.S. Environmental Protection Agency. 